Article

\title{
An Empirical Study on Students' Academic Wellbeing and Sustainable Development in Live Webcast Classes
}

\author{
Huani Liu ${ }^{1, *}$, Minjuan Wang ${ }^{2}$, Hengling Wan ${ }^{3}$, Yifan Lyu ${ }^{4}$ and Haorong Zhu ${ }^{5}$ \\ 1 School of Education, Shanghai International Studies University, Shanghai 200083, China \\ 2 Learning Design and Technology, San Diego State University, San Diego, CA 92182, USA; mwang@sdsu.edu \\ 3 Moray House School of Education and Sport, The University of Edinburgh, Edinburgh EH8 8AQ, UK; \\ s2110460@ed.ac.uk \\ 4 School of English Studies, Shanghai International Studies University, Shanghai 200083, China; \\ 0203100255@shisu.edu.cn \\ 5 School of Statistics, Beijing Normal University, Beijing 100875, China; 202022011150@mail.bnu.edu.cn \\ * Correspondence: liuhuani0816@shisu.edu.cn
}

Citation: Liu, H.; Wang, M.; Wan, H.; Lyu, Y.; Zhu, H. An Empirical Study on Students' Academic Wellbeing and Sustainable Development in Live Webcast Classes. Sustainability 2021, 13, 501. https://doi.org/10.3390/ su13020501

Received: 22 December 2020 Accepted: 29 December 2020 Published: 7 January 2021

Publisher's Note: MDPI stays neutral with regard to jurisdictional clai$\mathrm{ms}$ in published maps and institutional affiliations.

Copyright: (C) 2021 by the authors. Licensee MDPI, Basel, Switzerland. This article is an open access article distributed under the terms and conditions of the Creative Commons Attribution (CC BY) license (https:// creativecommons.org/licenses/by/ $4.0 /)$.

\begin{abstract}
In recent years, live webcast classes have been increasingly used in China as an approach to alleviating educational poverty through equal access to high-quality education. Many schools in impoverished areas have managed to increase their proportions of students entering college by introducing the new model. While celebrating improved learning outcomes of a small percentage of students, educators should also be concerned about the overall academic wellbeing and sustainable development of less successful students. In the present study, academic wellbeing was conceptualized as a multidimensional construct covering seven dimensions, namely Empathy, Support, Responsiveness, Reliability, Tangibility, Self-efficacy and Buoyancy. Data were collected from 136 twelfth-grade students who had studied in live webcast classes. The results show that the overall academic wellbeing in live webcast classes was consistent among students of different academic performance levels, but the specific dimensions of academic wellbeing that they think mostly need improvement varied among different student groups. The findings of this study suggest that learner wellbeing and sustainability can be enhanced by closer collaboration between live webcast instructors and local teachers in instructional materials design, exercise and test questions' compilation, as well as students' self-study facilitation. The degree to which a local teacher should be involved in classroom teaching depends on the students' academic level and learning needs.
\end{abstract}

Keywords: academic wellbeing; live webcast class; instructional design; educational poverty alleviation

\section{Introduction}

Over the past decades, a consistent effort has been made by the Chinese government to reduce poverty, as demonstrated in programmatic documents for guiding poverty alleviation work such as the "Seven-Year Priority Poverty Alleviation Program (1994-2000)" and the "National Program for Rural Poverty Alleviation (2001-2010)". Among various means of poverty alleviation, "ensuring that kids from the poor areas have access to good education is an important way to ensure that poverty will not be passed on from this generation to the next" [1]. In July 2013, an educational poverty alleviation initiative was introduced by China's Ministry of Education and three other departments, aiming to enhance sustainability efforts and eradicate poverty by elevating educational quality in poor areas [2]. Within this context, a new educational model—the Live Webcast Teaching Model-was introduced and turned out to be successful in addressing the long-standing problem of educational resource scarcity in China's poverty-stricken areas.

The model was initially established by several online schools in Beijing in the late 1990s [3] and carried forward by other schools around the nation. Among them is the Online school of Chengdu No. 7 High School. A report of their exemplary webcast classes 
went viral on social media at the end of the year 2018. Established in 1905, Chengdu No. 7 High School is a nationally renowned high school and was honored by China's Education Ministry as a "National-level Model High School" in 2000. Its Internet school, established in 2002, has so far partnered with over 300 schools and served nearly 300,000 students. As of today, it live broadcasts its classes online to over 8900 teachers and 80,000 students from over 250 schools in poor areas nationwide every day. By 2020, the school had helped 143 students from poor areas enter Tsinghua University and Peking University (China's top two universities) and helped countless students enter other prestigious universities [4]. Free from the limitation of space, live webcast teaching enables high-quality educational resources to be shared nationwide and is believed to go a long way to achieving educational equity and boosting the wellbeing of children in poor areas.

Despite such achievements and potential benefits, problems exist such as insufficient classroom interaction, students' failure to keep up with the online instructions, and the weakened role of local teachers [5,6]. Problems such as these raise concerns over students' academic wellbeing in live webcast classes: Are they content with their academic wellbeing? Do they receive sufficient support from their school and online instructors? Are there any problems in the new teaching model? In what ways can students' academic wellbeing be enhanced? To address these issues, this study explored twelfth-graders' academic wellbeing in live webcast classes in Yuexi High School using the SERVQUAL model to conceptualize the concept of academic wellbeing.

\section{Literature Review}

\subsection{Live Webcast Teaching as the Latest Form of Distance Education}

In the Live Webcast Teaching Model (See Figure 1), a teaching session in a remote classroom (always from a high-quality school) is live broadcasted from the Web to one or more local classes (mostly from low-quality schools in less-developed areas). The local students learn by joining the broadcast sessions via a networked computer screen, using exactly the same textbooks and other materials as those in the remote classroom. The local teacher's primary responsibility is not teaching but organizing the class and assisting the students when needed.

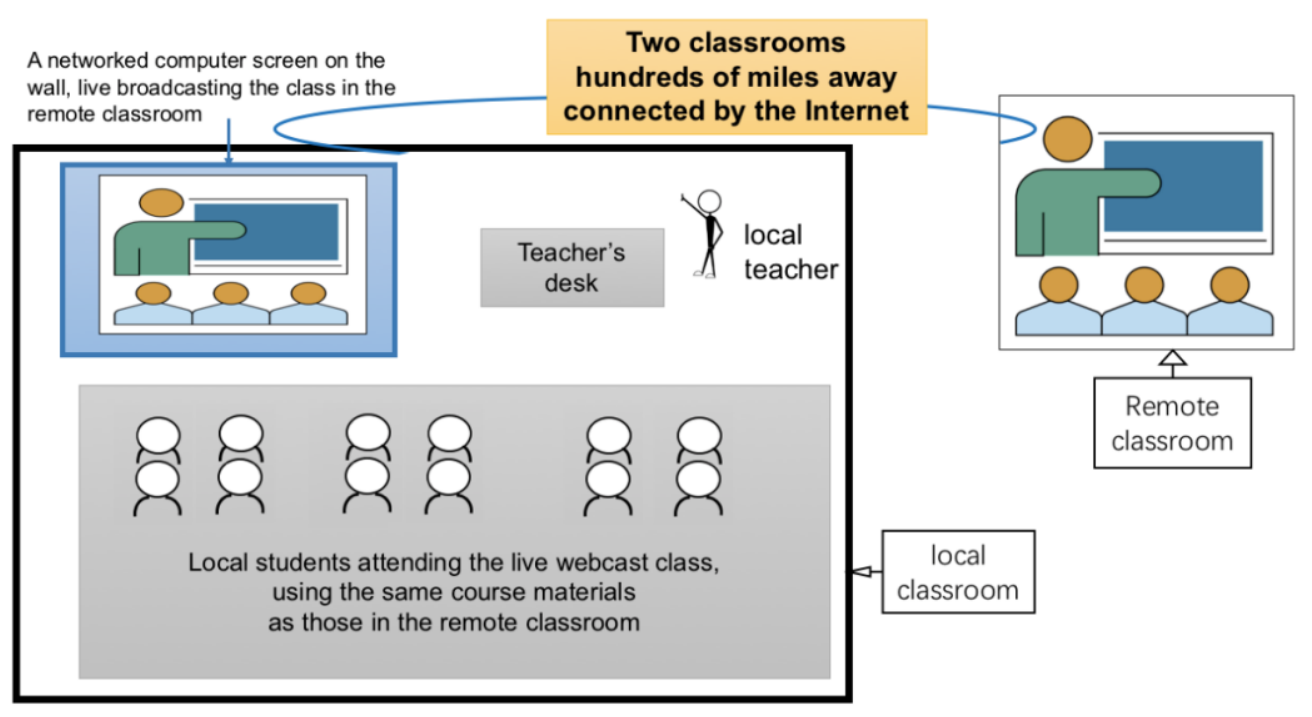

Figure 1. Live webcast teaching model.

Live webcast teaching is one of the latest forms of distance education. "The development of distance education can be structured into three generations of technological innovation-correspondence, telecommunications, and computers" [7]. With a networked mobile device, learners can gain access to a learning platform anytime, 
anywhere, so distance learning is no longer restricted to a computer desk but becomes "mobile". Whether mobile or not, the latest forms of distance education can be divided into "asynchronous teaching", where students learn by using pre-made teaching content or videoed sessions, and "synchronous teaching", where teachers teach by live streaming. Live streaming teaching also takes various forms such as one-on-one vs. one-to-many and online teaching only vs. live webcasting the traditional classroom-based offline teaching. All these forms of distance education are shown in Figure 2. In this study, live webcast teaching refers to the one-to-many synchronous teaching where face-to-face teaching sessions in a traditional classroom are shared with other classes in different places of the country via online live broadcast.

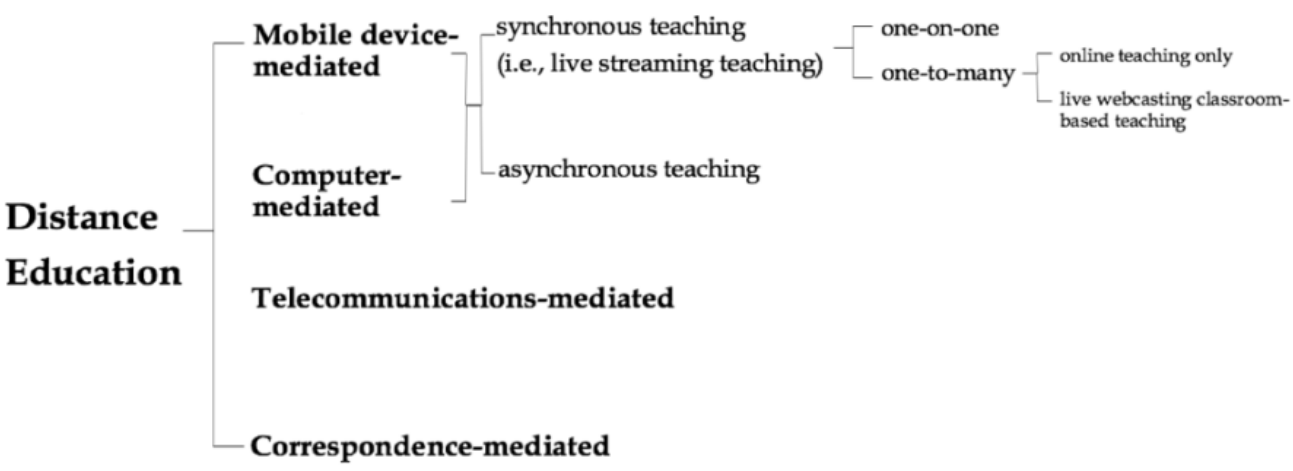

Figure 2. Various forms of distance education.

A rather new concept, live webcast teaching has not gained much attention of researchers. A search of Chinese Social Sciences Citation Index journals on the China National Knowledge Internet Platform with key words such as "live webcast teaching/class/education" and "streaming media-based distance teaching" ended up with a list of 32 journal articles, most of which are about the integration of streaming/webcast technology in traditional education or live streaming teaching targeted at online students only-for instance, the combination of webcast classes and offline courses in primary and secondary education [8] and the application of video-on-demand technology and live broadcasting in distance teaching [9]. Only one study examines "live webcast teaching" as defined in this study; Li and colleagues (2009) took the Internet school of Chengdu No. 7 High School as an example, evaluating the input, process, and effect of live webcast teaching in senior high schools [10].

\subsection{Student Wellbeing}

Previous studies on adolescent students' wellbeing mainly address the following three issues: (a) determinants or influence factors of students' wellbeing, such as a student's perception of the school climate and learning environment [11,12], interpersonal relations [13-16], parental involvement [17], progressive tests [18], and the use of social media [19,20]; (b) supporting students' wellbeing at school-methods and approaches such as wellbeing-oriented education [21], gratitude interventions [22], the skills for life program [23], and locating student voice [24]; (c) understanding students' wellbeing within various contexts such as students in transition to a higher school [25], students from refugee and migrant backgrounds [26], and students with intellectual disabilities [27]. These studies mostly focus on the subjective, psychological, and mental wellbeing of the students, i.e., the students' sense of happiness as human beings rather than satisfaction with their learning experience as classroom performers. Our study aims to examine the latter, defined as the students' academic wellbeing in a specific learning context such as live webcast classes.

In regard to research subjects, few studies have investigated the wellbeing of Chinese school children in poor areas. Lan and Moscardino (2019) examined the effects of perceived teacher-student relationships and grit on student wellbeing by making a comparison 
between urban stay-behind early adolescents and their non-stay-behind counterparts in mainland China [15]. Cui (2018) investigated the live webcast chemistry classes in Shilin No. 1 High School, a partner school of Chengdu No. 7 High School, and analyzed existing problems such as students' subjectivity as active learners being constrained and students' failure to follow the webcast instructions due to a disadvantage in academic level, learning ability, and learning habits [28]. Cui's conclusions are rather self-evidentit is natural for the under-educated students in impoverished areas to feel frustrated in a "synchronous" class offered by a national top school. Yet where specifically does the frustration come from? What do they perceive as being positive or negative about webcast classes? Drawing upon the Service Quality model, we designed a survey tool to measure the students' academic wellbeing in the new mode of education.

\subsection{SERVQUAL Model}

The SERVQUAL (Service Quality) model, also known as the "expectation-perception model", is a questionnaire-based tool for service quality assessment. Proposed by the American marketing scientist Parasuraman and his colleagues in 1988 [29], the model measures service quality across five dimensions, namely Tangibility, Reliability, Responsiveness, Support, and Empathy. Service quality (SQ) is measured by comparing customers' expectations (E) before a service encounter and their perceptions $(\mathrm{P})$ of the actual service delivered. The idea can be expressed in the following equation, which defines service quality level as the value difference between perceived service and expected service:

$$
S Q=P-E
$$

The model was initially applied to service quality evaluation in various business contexts such as green products, tourism, banking, and exhibitions [30-33]. In the field of education, the SERVQUAL model has been used mostly for the assessment of library services [34-36] and sometimes for evaluating the quality of professional degree programs [37] and distance learning support services [38].

The model is also applicable to the evaluation of students' wellbeing in live webcast classes: In the Tangibility dimension, the quality of tangible teaching facilities and environment is measured; the Reliability dimension examines instructors' abilities to conduct effective live webcast teaching; "Responsiveness" relates to instructors' responses to students' needs and feedback; "Support" describes how schools facilitate live webcast teaching; "Empathy" is demonstrated by instructors' awareness of and efforts in generating classroom interaction, offering support, and showing affection. Considering that all these dimensions point to external factors (instructor, school, classroom, and equipment) and that learner factors also contribute to a student's sense of wellbeing in class, we decided to add two dimensions to fill in the gap-the students' Self-efficacy and Buoyancy in live webcast learning.

Using the modified SERVQUAL model as a framework, this study conceptualized academic wellbeing and designed a survey tool to measure students' academic wellbeing in live webcast classes (see Section 3).

\section{Research Design}

\subsection{Survey Tool}

The survey tool used in this study is the Students' Academic Wellbeing in Live Webcast Classes Survey Questionnaire. The first part of the questionnaire collects the respondent's personal information, including age, gender, and academic performance ranking, and then asks about the school subjects that they learned in live webcast classes, the benefits from such learning, whether their academic performance improved, and why or why not.

In the second part, twenty-two statements are constructed to measure academic wellbeing across seven dimensions (see Table 1). For each statement, a five-point Likert scale is used to measure both students' expectations and their perceptions: The participants were invited to indicate the degree to which each statement is true for them by choosing a 
number ranging from 1 to 5; points 5, 4, 3, 2, and 1, respectively, mean "Absolutely true for me", "True for me", "Not sure", "Untrue for me", and "Not true for me at all".

Table 1. Evaluation scale of students' academic wellbeing in live webcast classes.

\begin{tabular}{|c|c|}
\hline Dimension & Items \\
\hline \multirow[t]{2}{*}{ Empathy } & $\begin{array}{l}\text { 1. The instructors always answer our questions when we have } \\
\text { any. }\end{array}$ \\
\hline & $\begin{array}{l}\text { 2. The instructors adjust difficult levels of tests according to our } \\
\text { knowledge levels. }\end{array}$ \\
\hline \multirow[t]{2}{*}{ Support } & 3. The live webcast class gets adequate support from our school. \\
\hline & 4. The instructors often ask us questions in class. \\
\hline \multirow{4}{*}{ Responsiveness } & 5. The instructors can often create a lively class atmosphere. \\
\hline & $\begin{array}{l}\text { 6. The instructors often share learning materials with us after } \\
\text { class. }\end{array}$ \\
\hline & $\begin{array}{l}\text { 7. The instructors respect our opinions and often take our } \\
\text { advice. }\end{array}$ \\
\hline & 8. The instructors are knowledgeable. \\
\hline \multirow{4}{*}{ Reliability } & 9. The instructors have rich teaching experience. \\
\hline & $\begin{array}{l}\text { 10. The instructions are clear, well-organized, and easy to } \\
\text { understand. }\end{array}$ \\
\hline & 11. The instructors' teaching methods are novel and creative. \\
\hline & 12. The picture in the live webcast is clear and smooth. \\
\hline \multirow{4}{*}{ Tangibility } & 13. The sound in the live webcast is clear and smooth. \\
\hline & 14. Our classroom is bright, spacious, and airy. \\
\hline & $\begin{array}{l}\text { 15. The multimedia and projector equipment in our classroom is } \\
\text { in good condition. }\end{array}$ \\
\hline & $\begin{array}{l}\text { 16. I learn better in live webcast classes than in local teachers' } \\
\text { classes. }\end{array}$ \\
\hline \multirow[t]{4}{*}{ Self-efficacy } & 17. Live webcast classes boost my academic performance. \\
\hline & $\begin{array}{l}\text { 18. The course contents are neither too easy nor too difficult for } \\
\text { me. }\end{array}$ \\
\hline & $\begin{array}{l}\text { 19. I am able to grasp all the learning contents in live webcast } \\
\text { classes. }\end{array}$ \\
\hline & $\begin{array}{l}\text { 20. Attending live webcast classes is an enjoyable experience for } \\
\text { me. }\end{array}$ \\
\hline \multirow{2}{*}{ Buoyancy } & $\begin{array}{l}\text { 21. Attending live webcast classes is a rewarding experience for } \\
\text { me. }\end{array}$ \\
\hline & 22. I will be happy to continue to study in live webcast classes. \\
\hline
\end{tabular}

\subsection{Participants and Data Collection}

The participants of this study were 136 twelfth-graders from Yuexi High School in Yuexi County, Liangshan Yi Autonomous Prefecture of China's Sichuan Province. Yuexi County is rated as a poor county of Sichuan Province in southwestern China. Within the context of educational poverty alleviation, the present study will hopefully shed some light on how to improve live webcast teaching for schools in underdeveloped areas, balancing short-term exam result improvement with long-term sustainability in both students' personal growth and the poor areas' educational development.

Altogether, 160 students completed a questionnaire survey in February 2019, and 136 copies of the valid questionnaire were collected. By the time the students participated in the questionnaire survey, they had attended live webcast classes led by the Online School of Chengdu No. 7 High School for at least one semester.

\subsection{Data Analysis and Validation}

SPSS 19.0 software was used to analyze the two sets of data: students' expectations of live webcast classes before they started the distance learning and their perceptions of the actual experience in live webcast classes. 
The Kaiser-Meyer-Olkin (KMO) test is used to study the partial correlation between variables. Generally, when the KMO value is 0.9 or above, the effect is the best; when it exceeds 0.7 , the data are suitable for factor analysis. The KMO values here are 0.841 and 0.845 (concerning Expectation and Perception, respectively; see Table 2), both exceeding 0.7, indicating that these data are suitable for factor analysis. The significance value of Bartlett's spherical test is less than 0.01 . It means that there is a significant correlation between the variables, also indicating that the data are suitable for factor analysis.

Table 2. KMO test and Bartlett's test results.

\begin{tabular}{cccc}
\hline \multirow{2}{*}{ Test Method } & Data Type & \multicolumn{2}{c}{ Results } \\
\cline { 2 - 4 } & Expectation & Perception \\
\hline \multirow{2}{*}{ KMO } & $\begin{array}{c}\text { KMO Measure of } \\
\text { Sampling Adequacy }\end{array}$ & 0.841 & 0.845 \\
\hline \multirow{2}{*}{$\begin{array}{c}\text { Bartlett's Test of } \\
\text { Sphericity }\end{array}$} & Approx. Chi-Square & 1439.768 & 1354.951 \\
\cline { 2 - 4 } & df & 231 & 231 \\
\cline { 2 - 4 } & Sig. & 0.000 & 0.000 \\
\hline
\end{tabular}

The factor analysis results show that the total variance explained by the Expectation survey is $71.297 \%$ (see Table 3), and that of the Perception survey is $70.54 \%$ (see Table 4 ), indicating that the questionnaire has good structural validity.

Table 3. Total variance explained (Expectation).

\begin{tabular}{|c|c|c|c|c|c|c|c|c|c|}
\hline \multirow{2}{*}{ Item } & \multicolumn{3}{|c|}{ Initial Eigenvalues } & \multicolumn{3}{|c|}{$\begin{array}{l}\text { Extraction Sums of Squared } \\
\text { Loadings }\end{array}$} & \multicolumn{3}{|c|}{$\begin{array}{c}\text { Rotation Sums of Squared } \\
\text { Loadings }\end{array}$} \\
\hline & Total & $\begin{array}{c}\% \text { of } \\
\text { Variance }\end{array}$ & $\begin{array}{l}\text { Cumulative } \\
\%\end{array}$ & Total & $\begin{array}{c}\% \text { of } \\
\text { Variance }\end{array}$ & $\begin{array}{l}\text { Cumulative } \\
\%\end{array}$ & Total & $\begin{array}{c}\% \text { of } \\
\text { Variance }\end{array}$ & $\begin{array}{l}\text { Cumulative } \\
\%\end{array}$ \\
\hline 1 & 7.318 & 33.263 & 33.263 & 7.318 & 33.263 & 33.263 & 2.927 & 13.305 & 13.305 \\
\hline 2 & 2.357 & 10.713 & 43.976 & 2.357 & 10.713 & 43.976 & 2.855 & 12.977 & 26.281 \\
\hline 3 & 1.555 & 7.070 & 51.046 & 1.555 & 7.070 & 51.046 & 2.331 & 10.597 & 36.879 \\
\hline 4 & 1.275 & 5.795 & 56.841 & 1.275 & 5.795 & 56.841 & 2.216 & 10.071 & 46.949 \\
\hline 5 & 1.245 & 5.661 & 62.502 & 1.245 & 5.661 & 62.502 & 2.108 & 9.583 & 56.533 \\
\hline 6 & 0.999 & 4.542 & 67.045 & 0.999 & 4.542 & 67.045 & 2.064 & 9.381 & 65.913 \\
\hline 7 & 0.936 & 4.252 & 71.297 & 0.936 & 4.252 & 71.297 & 1.184 & 5.384 & 71.297 \\
\hline 8 & 0.841 & 3.821 & 75.118 & & & & & & \\
\hline 9 & 0.751 & 3.414 & 78.532 & & & & & & \\
\hline 10 & 0.628 & 2.855 & 81.387 & & & & & & \\
\hline 11 & 0.560 & 2.543 & 83.930 & & & & & & \\
\hline 12 & 0.529 & 2.407 & 86.337 & & & & & & \\
\hline 13 & 0.482 & 2.193 & 88.530 & & & & & & \\
\hline 14 & 0.415 & 1.888 & 90.418 & & & & & & \\
\hline 15 & 0.383 & 1.739 & 92.157 & & & & & & \\
\hline 16 & 0.342 & 1.555 & 93.712 & & & & & & \\
\hline 17 & 0.320 & 1.455 & 95.167 & & & & & & \\
\hline 18 & 0.293 & 1.333 & 96.500 & & & & & & \\
\hline 19 & 0.265 & 1.207 & 97.707 & & & & & & \\
\hline 20 & 0.236 & 1.071 & 98.778 & & & & & & \\
\hline 21 & 0.176 & 0.802 & 99.580 & & & & & & \\
\hline 22 & 0.092 & 0.420 & 100.000 & & & & & & \\
\hline
\end{tabular}


Table 4. Total variance explained (Perception).

\begin{tabular}{|c|c|c|c|c|c|c|c|c|c|}
\hline \multirow{2}{*}{ Item } & \multicolumn{3}{|c|}{ Initial Eigenvalues } & \multicolumn{3}{|c|}{$\begin{array}{l}\text { Extraction Sums of Squared } \\
\text { Loadings }\end{array}$} & \multicolumn{3}{|c|}{$\begin{array}{c}\text { Rotation Sums of Squared } \\
\text { Loadings }\end{array}$} \\
\hline & Total & $\begin{array}{c}\% \text { of } \\
\text { Variance }\end{array}$ & $\begin{array}{l}\text { Cumulative } \\
\%\end{array}$ & Total & $\begin{array}{c}\% \text { of } \\
\text { Variance }\end{array}$ & $\begin{array}{l}\text { Cumulative } \\
\%\end{array}$ & Total & $\begin{array}{c}\% \text { of } \\
\text { Variance }\end{array}$ & $\begin{array}{l}\text { Cumulative } \\
\%\end{array}$ \\
\hline 1 & 7.285 & 33.115 & 33.115 & 7.285 & 33.115 & 33.115 & 3.123 & 14.195 & 14.195 \\
\hline 2 & 2.067 & 9.396 & 42.511 & 2.067 & 9.396 & 42.511 & 2.627 & 11.942 & 26.137 \\
\hline 3 & 1.723 & 7.830 & 50.341 & 1.723 & 7.830 & 50.341 & 2.625 & 11.930 & 38.067 \\
\hline 4 & 1.346 & 6.119 & 56.459 & 1.346 & 6.119 & 56.459 & 2.056 & 9.347 & 47.414 \\
\hline 5 & 1.185 & 5.386 & 61.846 & 1.185 & 5.386 & 61.846 & 1.896 & 8.619 & 56.034 \\
\hline 6 & 0.968 & 4.402 & 66.248 & 0.968 & 4.402 & 66.248 & 1.818 & 8.266 & 64.299 \\
\hline 7 & 0.944 & 4.292 & 70.540 & 0.944 & 4.292 & 70.540 & 1.373 & 6.241 & 70.540 \\
\hline 8 & 0.831 & 3.778 & 74.318 & & & & & & \\
\hline 9 & 0.714 & 3.244 & 77.563 & & & & & & \\
\hline 10 & 0.651 & 2.961 & 80.523 & & & & & & \\
\hline 11 & 0.612 & 2.782 & 83.306 & & & & & & \\
\hline 12 & 0.524 & 2.382 & 85.687 & & & & & & \\
\hline 13 & 0.496 & 2.255 & 87.942 & & & & & & \\
\hline 14 & 0.433 & 1.966 & 89.909 & & & & & & \\
\hline 15 & 0.381 & 1.732 & 91.640 & & & & & & \\
\hline 16 & 0.361 & 1.639 & 93.279 & & & & & & \\
\hline 17 & 0.334 & 1.518 & 94.797 & & & & & & \\
\hline 18 & 0.324 & 1.471 & 96.268 & & & & & & \\
\hline 19 & 0.256 & 1.165 & 97.433 & & & & & & \\
\hline 20 & 0.232 & 1.056 & 98.489 & & & & & & \\
\hline 21 & 0.209 & 0.951 & 99.440 & & & & & & \\
\hline 22 & 0.123 & 0.560 & 100.000 & & & & & & \\
\hline
\end{tabular}

Extraction Method: Principal Component Analysis.

Cronbach's alpha reliability coefficient was used to measure the internal consistency reliability of the Expectation survey and the Perception survey, and the results show that the $\alpha$ coefficients are 0.899 and 0.898 , respectively, indicating that the questionnaire has good reliability.

\section{Results and Discussion}

\subsection{Descriptive Survey Results}

Before rating the 22 statements in the questionnaire, the respondents were requested to answer five multiple choice questions: (a) What are the benefits of attending live webcast classes? (b) Which school subjects have you learned in live webcast classes? (c) Did live webcast classes help improve your academic performance? If yes, (d) what do you think are the reasons? If not, (e) what do you think are the reasons?

The results (see Table 5) show that the students attended live webcast classes for nearly all school subjects, including Chinese, English, mathematics, chemistry, physics, biology, history, politics, geography, and other subjects. Therefore, the survey results were not subject-specific and are applicable to students' academic wellbeing in overall learning via live webcast class. A majority of the respondents $(80.15 \%)$ believed that live webcast teaching broadened their horizons, a most widely recognized benefit. Over a third of the respondents said that live webcast classes helped consolidate their fundamental knowledge, and another third said the new teaching model tapped into their learning potential, enabling them to acquire much more advanced knowledge than they would have in local classes. 
Table 5. Descriptive data.

\begin{tabular}{lllll}
\hline \multirow{2}{*}{ Subjects } & Chinese (68.38\%) & English (50.00\%) & Mathematics (48.53\%) & $\begin{array}{l}\text { Chemistry/Physics/Biology } \\
\mathbf{( 5 7 . 3 5 \% )}\end{array}$ \\
\cline { 2 - 5 } & History/Politics/Geography (30.15\%) & PE/Music/Art (0.02\%) & others $(9.56 \%)$ \\
\hline Benefits & $\begin{array}{l}\text { Consolidating } \\
\text { foundation }(35.29 \%)\end{array}$ & $\begin{array}{l}\text { advanced knowledge } \\
\text { acquisition }(36.76 \%)\end{array}$ & $\begin{array}{l}\text { Broadening horizons } \\
(80.15 \%)\end{array}$ & \\
\hline Impact & Helpful (68.38\%) & not helpful (31.62\%) & & others $(7.53 \%)$ \\
\hline Why helpful & $\begin{array}{l}\text { Instructors' abilities } \\
(58.06 \%)\end{array}$ & $\begin{array}{l}\text { effective model } \\
(50.54 \%) ;\end{array}$ & $\begin{array}{l}\text { local teachers' support } \\
(58.06 \%)\end{array}$ & others $(32.56 \%)$ \\
\hline Why not helpful & $\begin{array}{l}\text { Instructors' abilities } \\
(9.03 \%)\end{array}$ & $\begin{array}{l}\text { ineffective model } \\
(55.81 \%)\end{array}$ & $\begin{array}{l}\text { lack of local support } \\
(20.93 \%)\end{array}$ & \\
\hline
\end{tabular}

As for the model's influence on academic performance, about $68 \%$ of the respondents claimed a positive impact resulting from a combination of the effective teaching model, better course instructors from Chengdu No. 7 High school, local teachers' assistance, and affordance of supplementary study materials. Other reasons they suggested include the good learning atmosphere of Chengdu No. 7 High School and the force of examples set by outstanding learners from that school. By contrast, $31.62 \%$ of the respondents said that live webcast teaching failed to improve their academic performance and over half of them considered the teaching model ineffective for them. The main reasons for the ineffectiveness were the students' low academic proficiency, poor learning abilities, and consequent failure to keep up with the live webcast teaching. Another two factors that made the difference are the availability of supplementary study materials and support from local teachers. Therefore, live webcast teaching is challenging for low-level students, especially when local support is insufficient.

On the basis of the descriptive data analysis, we conducted an overall analysis of all the respondents' academic wellbeing and then a stratification analysis of the data about students of different academic levels. The results are as follows.

\subsection{Students' Overall Academic Wellbeing}

Survey results (see Table 6) show that the highest mean value and the lowest degree of dispersion both fell to the Reliability dimension, meaning that the students think highly of the teaching abilities of the live webcast instructors. The mean values on the Responsiveness and Empathy dimensions were lower by comparison. Although some respondents wished to communicate with the instructors in the remote classroom, others accepted the reality that it was barely possible for them to fully interact with the instructors, considering the fact that one instructor was often connected with hundreds or thousands of students online at the same time.

Table 6. Service quality (SQ) scores by item.

\begin{tabular}{cccccccccc}
\hline No. & Min. & Max. & Mean & SD. & No. & Min. & Max. & Mean & SD. \\
\hline 1 & -4 & 2 & -0.52206 & 1.305908 & 12 & -4 & 4 & -0.37500 & 1.265710 \\
2 & -4 & 4 & -0.40441 & 1.238943 & 13 & -4 & 3 & -0.32353 & 1.070200 \\
3 & -4 & 2 & -0.05882 & 1.089824 & 14 & -3 & 2 & -0.09559 & 0.991721 \\
4 & -4 & 4 & -0.13235 & 1.235557 & 15 & -3 & 3 & -0.18382 & 1.112775 \\
5 & -4 & 4 & -0.30147 & 1.244517 & 16 & -3 & 3 & -0.16176 & 1.164554 \\
6 & -4 & 3 & -0.41912 & 1.358823 & 17 & -3 & 3 & -0.46324 & 1.123990 \\
7 & -4 & 3 & -0.57358 & 1.216506 & 18 & -4 & 4 & -0.38235 & 1.283715 \\
8 & -4 & 4 & -0.18382 & 0.956420 & 19 & -4 & 3 & -0.05147 & 1.024120 \\
9 & -2 & 2 & -0.22794 & 0.804097 & 20 & -3 & 3 & -0.18382 & 1.099480 \\
10 & -2 & 4 & -0.10294 & 0.901628 & 21 & -3 & 2 & -0.25000 & 0.905457 \\
11 & -2 & 3 & -0.15441 & 0.930518 & 22 & -3 & 3 & -0.11029 & 1.004935 \\
\hline
\end{tabular}


Table 6 shows that the standard deviation of each item was about 1 , indicating that data dispersion was small and wellbeing levels of different learners were convergent. The smallest differences between the Perception $(P)$ value and the corresponding Expectation $(E)$ value went to items $19(=-0.051), 3(=-0.059)$, and $14(=-0.096)$, meaning that the students were relatively satisfied with the teaching quality, the school support, and the classroom environment. The three items with the lowest scores were $7(=-0.574), 1(=-0.522)$, and $17(=-0.463)$, meaning that the students were unhappy about the instructors' failure to listen to them and answer their questions, and live webcast classes did not improve their academic performance as much as they had expected.

The mean score of each dimension was calculated as an average of the mean values of all the items in the same dimension (see Table 7). The final score of SQ was -0.25 , an average of the mean scores across all the seven dimensions, indicating that students perceptions of the live webcast class experiences did not meet their expectations.

Table 7. SQ scores by dimension.

\begin{tabular}{ccccc}
\hline No. & Min. & Max. & Mean & SD. \\
\hline Empathy & -4 & 3 & -0.46 & 1.27422461 \\
Support & -3.5 & 3 & -0.13 & 1.127448316 \\
Responsiveness & -4 & 3.5 & -0.36 & 1.275343218 \\
Reliability & -2.5 & 3.2 & -0.14 & 0.917897883 \\
Tangibility & -3.5 & 3 & -0.24 & 1.120073737 \\
Self-efficacy & -3.5 & 3.25 & -0.26 & 1.164646463 \\
Buoyancy & -3 & 2.75 & -0.16 & 1.016196688 \\
Mean & -3.4 & 3.1 & -0.25 & 1.127975845 \\
\hline
\end{tabular}

To be specific, the highest scores went to the Support, Reliability, and Buoyancy dimensions, where the differences between the $P$ and $E$ values were minimal. Relatively speaking, the students were satisfied with school support and the instructors' teaching abilities; they enjoyed the live webcast classes, considered them helpful for their study, and were happy to continue to learn in these classes. The dimensions that scored the lowest were Responsiveness $(=-0.36)$ and Empathy $(=-0.46)$, indicating insufficiency in classroom interactions and teacher support and encouragement.

\subsection{Academic Wellbeing of Students of Different Academic Levels}

To understand the academic wellbeing of students of different academic levels, we grouped the respondents according to their performance in the latest school test; the high-level group ranked top 30\% in the class, the low-level group ranked bottom 30\% in the class, and the remaining $40 \%$ made up the medium-level group. The data were stratified by the three groups, and the results are shown in Table 8.

Table 8. SQ scores by academic level.

\begin{tabular}{cccc}
\hline & Top $\mathbf{3 0} \%$ & Middle $\mathbf{4 0} \%$ & Bottom $\mathbf{3 0} \%$ \\
\hline Empathy & -0.41 & -0.60 & -0.13 \\
Support & -0.09 & -0.22 & 0.09 \\
Responsiveness & -0.28 & -0.49 & -0.14 \\
Reliability & -0.18 & -0.16 & 0.06 \\
Tangibility & -0.22 & -0.24 & -0.34 \\
Self-efficacy & -0.24 & -0.33 & -0.11 \\
Buoyancy & -0.16 & -0.20 & -0.05 \\
Mean & -0.23 & -0.32 & -0.09 \\
\hline
\end{tabular}

The data reveal that although there are no significant differences among the groups, the low-level group's perceived wellbeing in live webcast classes was the closest to their expectations, followed by the high-level group, whilst the mediocre group has the greatest 
difference between the $E$ and $P$ values. Upon closer examination, the low-level group had the highest expectation value while the high-level group had the lowest; the high- and low-level groups had similar $P$ values; the medium-level group had the lowest $P$ value. It is also worth noting that the low-level group's scores on the Support and Reliability dimensions were positive, indicating that the instructors' professional competence and the school support for live webcast classes exceeded their expectations.

To further understand the cause of these differences, we calculated the mean $E$ value and the mean $P$ value assigned by all the respondents to each of the 22 items and then calculated each item's mean value given by the three student groups. Based on these data and the Importance-Performance Analysis (IPA) model proposed by Martilla and James (see Figure 3) [39], we drew three quadrant charts ( $P$ value in the horizontal axis and $E$ value in the vertical axis) to demonstrate areas where the current practice is satisfactory and needs no change (Quadrant 1), areas of over-supply (Quadrant 2), areas of lower priority for improvement (Quadrant 3), and areas most in need of improvement (Quadrant 4), as is demonstrated in Figures 4-6.

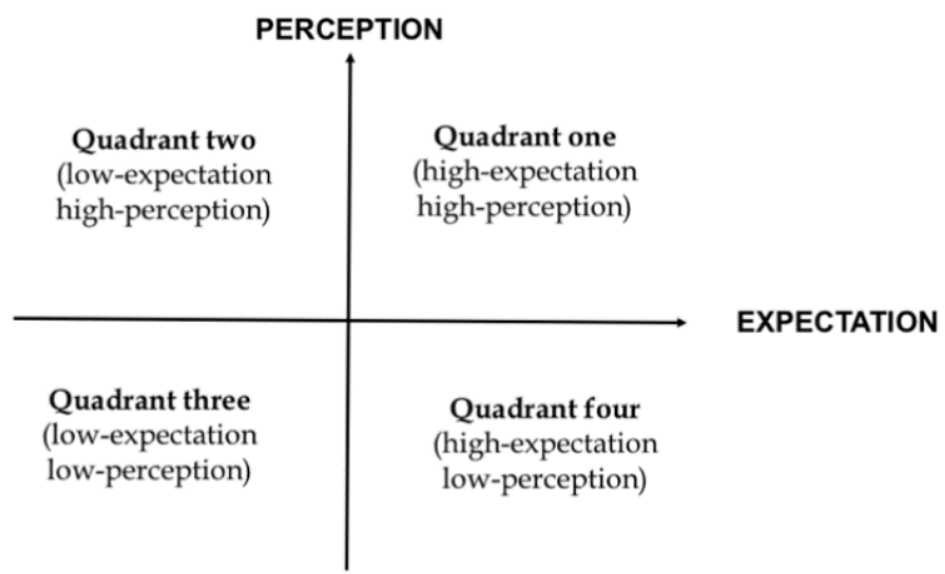

Figure 3. Expectation-perception quadrant diagram (Martilla and James, 1977).

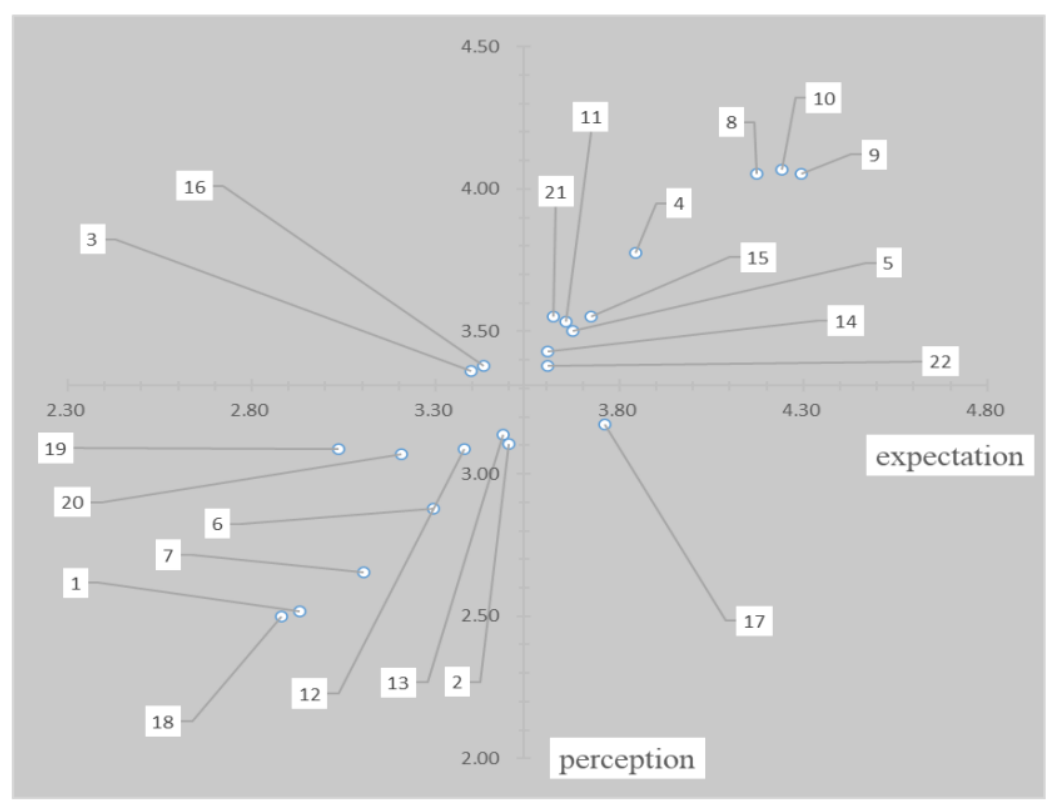

Figure 4. Expectation-perception quadrant diagram of the high-level group. 


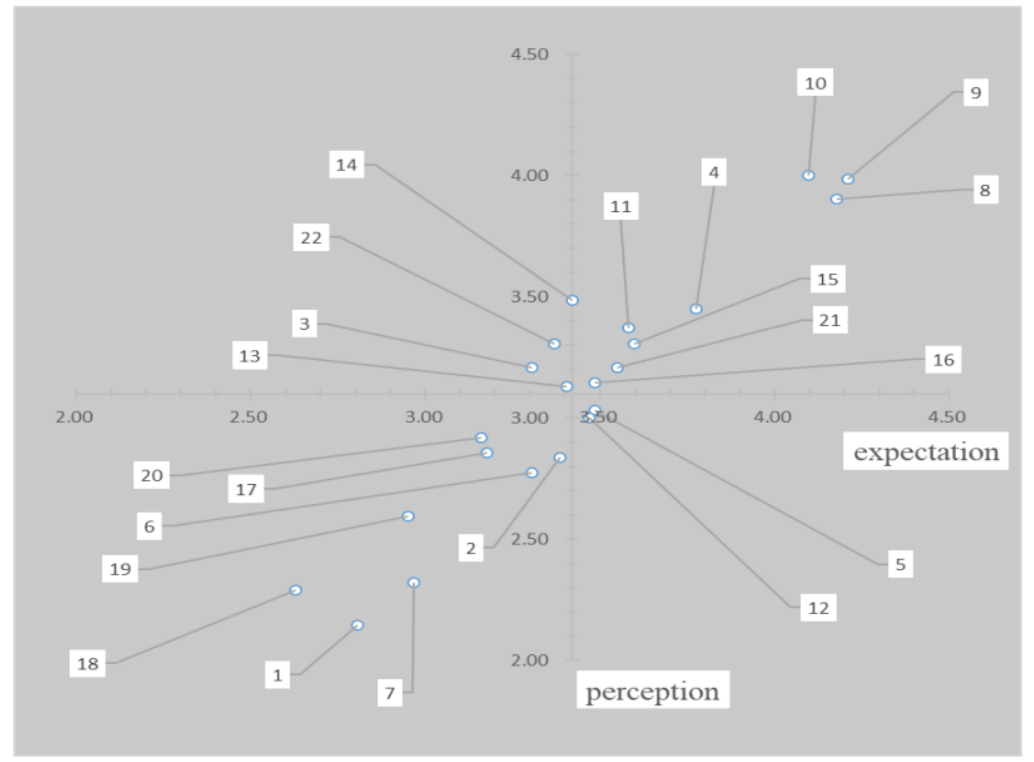

Figure 5. Expectation-perception quadrant diagram of the medium-level group.

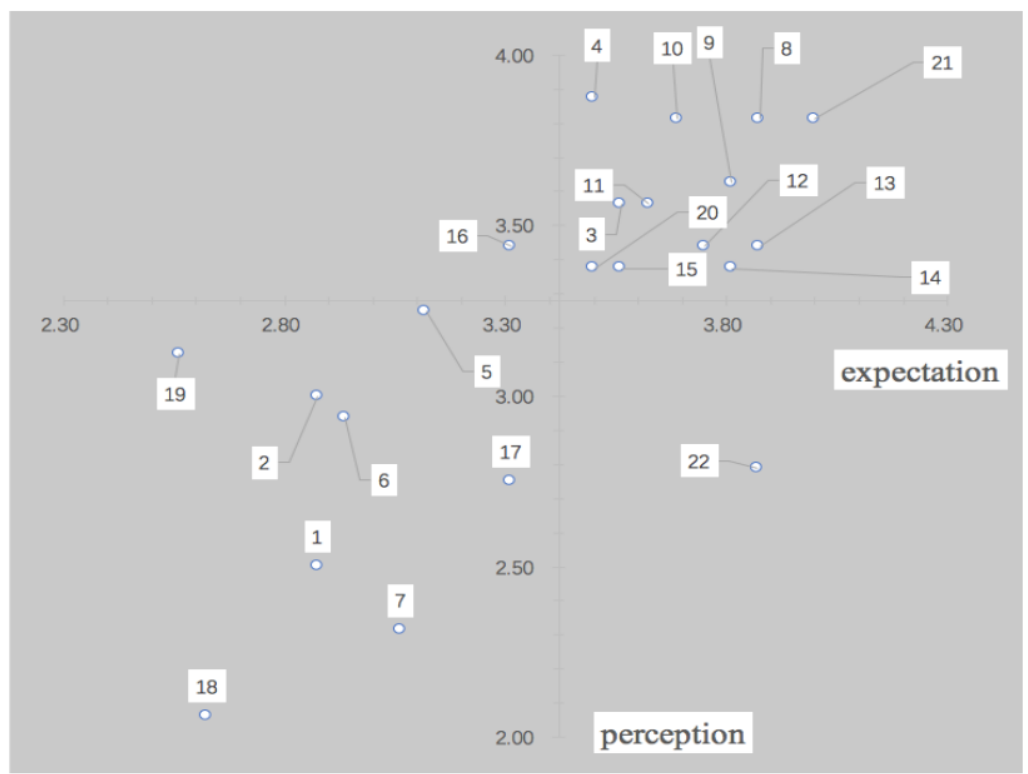

Figure 6. Expectation-perception quadrant diagram of the low-level group.

Overall, in the IPA analysis diagrams of the three student groups, 13 out of 22 items $(59 \%)$ fell on the same quadrant -7 on the first quadrant and 6 on the third. The items in the first quadrant of all the three diagrams were the $4 \mathrm{th}, 8 \mathrm{th}, 9 \mathrm{th}, 10 \mathrm{th}, 11 \mathrm{th}, 15 \mathrm{th}$, and 21st items. Among them, four items $(8,9,10$, and 11) are from the Reliability dimension, showing the students' high expectations and perceptions of the live webcast instructors' teaching abilities. The common items on the third quadrant of all the three diagrams were the 1st, 2nd, 6th, 7th, 18th, and 19th items. Among them, items 1 and 2 are about Empathy, 6 and 7 about Responsiveness, 18 and 19 about Self-efficacy. It seems that the students did not hold high expectations for classroom interaction and teacher attention and response, and they anticipated that the course contents in webcast classes would be more advanced than what they could grasp. Not surprisingly, their perceptions of the real learning experiences in all these aspects also turned out to be rather low.

No items were found in Quadrant 4 of all the three diagrams. It means that students of different academic levels had different needs for improving their academic wellbeing. 
Different strategies and approaches are then needed to cater for these different needs. The high-level group wished to improve their academic performance and school records most. The medium-level group hoped that the webcast equipment could work better and that instructors could interact more with the students and create a lively classroom atmosphere. For the low-level group, the only measurement item falling to the high expectation/low perception quadrant is 22 , which means that they had hoped to continuously study in live webcast classes but were thwarted after attending the class.

\section{Addressing Diversified Learner Needs by Cooperative Teaching}

As discussed above, due to various reasons such as fast-paced teaching, difficult course contents, and inadequate interaction and teacher attention and support, the students' experiences with live webcast classes were not as good as they had expected, resulting in an overall low level of academic wellbeing. The stratification data analysis revealed that students at high, medium, and low levels had different needs. To address the different learner needs, local teachers and live webcast instructors should be encouraged to work together both in and outside of classes.

\subsection{Cooperative Teaching in Class}

Experience shows that even students in the same class or school may differ greatly in knowledge mastery and learning abilities, so it is natural that students from a poor school may fail to keep up with the live webcast teaching offered by a national top school. To help students learn better, local teachers may group them according to their academic levels and provide them with the guidance needed.

Firstly, straight-A students with good learning skills can form a class and follow live webcast classes on their own without the involvement of a local teacher. Students will decide if they need one-on-one tutoring or a collective Q\&A session. This mode gives control to the students and encourage their independent learning, which will turn into higher learning efficiency and learning outcomes.

As for the students with mediocre grades, live webcast instructions should be combined with face-to-face teaching by local teachers. Our survey showed that the greatest expectation-perception gap for the medium-level group was in Responsiveness. However, since one live webcast class is often shared with multiple classes, there are barely any realtime interactions in class, and students' demands for interactions, individualized teaching, and emotional support from teachers are scarcely met. Therefore, we suggest dividing a class session into two sub-sections: about $30 \mathrm{~min}$ of live broadcasting for the delivery of key knowledge points, plus a 15-min face-to-face session led by local teachers who can use the time to recap, give a quiz, or start a Q\&A session with flexible time allocation. A hybrid modality such as this combines the advantages of online and offline teaching, making up for the absence of interactions and emotional support in live webcast classes.

For lower-level students, a more suitable modality might be the coupling of face-toface teaching with watching videoed lectures from live webcast classes. In comparison to live broadcasting, pre-made videos give local teachers greater autonomy in class since they are able to adjust the pace of teaching as needed. They may hit the pause button to explain a confusing point or skip a part of the video if the content is not suitable for the students; the students also have an opportunity to share their thoughts, ask questions, and start discussions in class.

\subsection{Collaboration Outside Class}

To better prepare local students for the high-quality yet challenging live webcast lessons, live webcast instructors may share their teaching plans, exercise questions, worksheets, and other course materials in advance with local teachers who can then select proper materials or simplify overly difficult ones for students to preview and practice.

Another thing that can be done is to film the live webcast sessions and edit the videos to make mini-lectures. Since the same subject knowledge is taught in webcast classes year 
after year, if the teaching sessions are filmed, local teachers can review the teaching videos and make short clips out of them to show the key points in each lecture. These video clips will serve as great learning materials for the local students who may watch them anywhere, anytime, as many times as they wish.

Thirdly, live webcast instructors can work with local teachers in preparing exercise questions of varying difficulty levels. Students from top schools often start with difficult questions directly since easier ones are not cognitively challenging for them. However, local students from poor schools need more practice at lower levels so that they can proceed in an orderly way and advance step by step. Before a webcast teaching session, the local teacher can encourage the students to preview the lesson and do some easier exercises so as to prepare for the more challenging exercises in class.

Another important way that teachers can collaborate outside of classes is to address students' questions individually. Since one teacher in the live webcast class is followed by many classes in different places in the country, it is impossible for them to take questions from all the students online at the same time. A practical solution may be for the local teachers to regularly collect students' questions and answer most of them, leaving some difficult questions for live webcast instructors who can conduct separate mini-sessions to each of the local classes, interacting with the students to accommodate their needs for more teacher attention and support.

Finally, live webcast instructors and local teachers can communicate regularly on students' progress, difficulties, and problems. In the process of daily teaching management, local teachers should collect students' feedback and identify problems in time and should try to solve the problems by communicating and cooperating with the school authority and course instructors. In this way, a virtuous circle can be formed so as to gradually enhance the students' academic wellbeing in live webcast classes.

\section{Conclusions}

Live webcast teaching is designed to fully tap into high-quality educational resources in the national top schools to improve the education of impoverished areas and lift people out of poverty in the long run. Based on the adapted SERVQUAL model, which measures students' academic wellbeing across seven dimensions (i.e., Empathy, Support, Responsiveness, Reliability, Tangibility, Self-efficacy, and Buoyancy), this study investigated 136 twelfthgraders' academic wellbeing in live webcast classes. The survey shows that the live webcast classes fell short in meeting the students' expectations. In addition, the specific aspects of academic wellbeing that are considered to mostly need improvement vary among student groups of different academic levels. These different needs can be met through cooperative teaching by live webcast instructors and local teachers both in class and outside class. In particular, giving full play to the roles of the local teachers and allocating part of the class time to face-to-face instruction can make up for the weaknesses of live webcast classes and meet the students' needs for individualized learning.

It is particularly worth mentioning that connecting schools in poor areas with those in developed regions through a network cable does not solve the educational poverty issue once and for all. Such a practice might be helpful in improving the learning outcomes of some students in the short run but it is not effective in fostering sustainable development of the poor areas and alleviating poverty in the long run. Aiming for sustainability in the educational development of underdeveloped areas, we must strengthen their own abilities to develop, for instance, by encouraging local teachers to participate in the class to varying degrees, to implement blended teaching, and to learn in doing. Only in this way can the local teachers grow professionally and, eventually, make their due effort to enhance the quality of the local education as well as the students' overall academic wellbeing in local schools. The real solution to educational poverty is a combination of short-term steps such as sharing high-quality resources from developed areas and long-term steps such as cultivating excellent local teachers and local schools. 
Author Contributions: Conceptualization, H.L. and M.W.; methodology, H.L., and H.W.; data collection, Y.L., and H.Z.; validation, H.W. and H.Z.; visualization, H.L., H.W., and H.Z.; writing-original draft preparation, H.L., H.W. and Y.L.; writing-review and editing, H.L. and M.W. All authors have read and agreed to the published version of the manuscript.

Funding: This research received no external funding.

Institutional Review Board Statement: Ethical review and approval were waived for this study because the institutions of the authors who participated in data collection do not require IRB review and approval. Informed Consent Statement: Not applicable.

Data Availability Statement: Data is contained within the article.

Conflicts of Interest: The authors declare no conflict of interest.

\section{References}

1. Xi, J. Common Development through Joint Efforts on Poverty Eradication. Keynote Speech Delivered at the 2015 Global Poverty Reduction \& Development Forum. Available online: http://www.xinhuanet.com/politics/2015-10/16/c_1116851045.htm (accessed on 10 May 2020).

2. Ministry of Education of the People's Republic of China. Opinions on the Implementation of Educational Poverty Alleviation Project. Available online: http:/ / www.cpad.gov.cn/art/2013/9/12/art_50_23748.html (accessed on 10 May 2020).

3. Dabai. The Report "A Screen that May Change One's Fate" Has Gone Viral: Is the Live Webcast Teaching Model of Chengdu No.7 High School Worth Spreading? Available online: http:/ /sc.qinxue100.com/news/gz/106515.html (accessed on 10 May 2020).

4. Chengdu, No. 7 High School. Getting to Know Our Net Class: The Educational Reform at the Internet School of Chengdu No.7 High School. Available online: http:/ / www.eastedu.org/Login (accessed on 10 November 2020).

5. Jiang, M.-H. Live remote teaching: Problems and solutions-Taking the Internet math class of Chengdu No.7 High School as an example. West. China Qual. Educ. 2017, 3, 191.

6. Li, G. Behind the Fate-Changing Screen: Pros and Cons in the Live Webcast of Chengdu NO.7 High School. 21st Century Busi-ness Herald. 27 December 2018. Available online: http:/ / epaper.21jingji.com/html/2018-12/27/content_99095.htm (accessed on 3 January 2021).

7. Garrison, D.R. Three generations of technological innovations in distance education. Distance Educ. 1985, 6, 235-241. [CrossRef]

8. Ni, J.-J.; Ding, S.L. O2O live webcast classroom teaching model and its practice. China Educ. Technol. 2017, 11, 114-118.

9. Chen, Y.; Zhang, M.-T.; Zheng, S.-H.; Sun, J.; Lin, S.-F. Application of the technology of video on demand and live broadcasting in distance teaching. Comput. Appl. Chem. 2002, 4, 489-491.

10. Li, S.; Wang, L.; Bai, B. The research on evaluation of the Live Broadcasting Video Distance Teaching Model in senior high schools. Open Educ. Res. 2009, 4, 86-92.

11. Aldridge, J.M.; Fraser, B.J.; Fozdar, F.; Ala'i, K.; Earnest, J.; Afari, E. Students' perceptions of school climate as determinants of wellbeing, resilience and identity. Improv. Sch. 2016, 19, 5-26. [CrossRef]

12. Turunen, M.; Toyinbo, O.; Putus, T.; Nevalainen, A.; Shaughnessy, R.; Haverinen-Shaughnessy, U. Indoor environmental quality in school buildings, and the health and wellbeing of students. Int. J. Hygen Environ. Health 2014, 217, 733-739. [CrossRef]

13. Heredia, D., Jr.; Sanchéz Gonzalez, M.L.; Rosner, C.M.; He, X.; Castillo, L.G.; Ojeda, L. The influence of loneliness and interpersonal relations on Latina/o middle school students' wellbeing. J. Lat. Educ. 2017, 16, 338-348. [CrossRef]

14. Powell, M.A.; Graham, A.; Fitzgerald, R.; Thomas, N.; White, N.E. Wellbeing in schools: What do students tell us? Aust. Educ. Res. 2018, 45, 515-531. [CrossRef]

15. Lan, X.Y.; Moscardino, U. Direct and interactive effects of perceived teacher-student relationship and grit on student wellbeing among stay-behind early adolescents in urban China. Learn. Individ. Differ. 2019, 69, 129-137. [CrossRef]

16. McCalman, J.; Benveniste, T.; Wenitong, M.; Saunders, V.; Hunter, E. "It's all about relationships": The place of boarding schools in promoting and managing health and wellbeing of Aboriginal and Torres Strait Islander secondary school students. Child. Youth Serv. Rev. 2020, 113. [CrossRef]

17. Thomas, V.; Muls, J.; De Backer, F.; Lombaerts, K. Middle school student and parent perceptions of parental involvement: Unravelling the associations with school achievement and wellbeing. Educ. Stud. 2020, 46, 404-442. [CrossRef]

18. Yielder, J.; Wearn, A.; Chen, Y.; Henning, M.A.; Weller, J.; Lillis, S.; Mogol, V.; Bagg, W. A qualitative exploration of student perceptions of the impact of progress tests on learning and emotional wellbeing. BMC Med. Educ. 2017, 17, 148. [CrossRef] [PubMed]

19. Lai, H.M.; Hsieh, P.J.; Zhang, R.C. Understanding adolescent students' use of Facebook and their subjective wellbeing: A genderbased comparison. Behav. Inf. Technol. 2019, 38, 533-548. [CrossRef]

20. Smith, R.; Morgan, J.; Monks, C. Students' perceptions of the effect of social media ostracism on wellbeing. Comput. Hum. Behav. 2017, 68, 276-285. [CrossRef]

21. Zhang, Y.F. Making students happy with wellbeing-oriented education: Case study of a secondary school in China. Asia Pac. Educ. Res. 2016, 25, 463-471. [CrossRef] 
22. Bono, G.; Mangan, S.; Fauteux, F.; Sender, J. A new approach to gratitude interventions in high schools that supports student wellbeing. J. Posit. Psychol. 2020, 15, 657-665. [CrossRef]

23. Pannebakker, F.D.; Van Genugten, L.; Diekstra, R.F.; Gravesteijn, C.; Fekkes, M.; Kuiper, R.; Kocken, P.L. A social gradient in the effects of the skills for life program on self-efficacy and mental wellbeing of adolescent students. J. Sch. Health 2019, 89, 587. [CrossRef]

24. Anderson, D.L.; Graham, A.P. Improving student wellbeing: Having a say at school. Sch. Eff. Sch. Improv. 2016, 27, 348366. [CrossRef]

25. Carmen, B.; Waycott, L.; Smith, K. Rock Up: An initiative supporting students' wellbeing in their transition to secondary school. Child. Youth Serv. Rev. 2011, 33, 167-172. [CrossRef]

26. Khawaja, N.G.; Ibrahim, O.; Schweitzer, R.D. Mental wellbeing of students from refugee and migrant backgrounds: The mediating role of resilience. Sch. Ment. Health 2017, 9, 284-293. [CrossRef]

27. Ommen, V.M. Educational quality of life: A merging of student experience, learning and wellbeing for students with intellectual disabilities. J. Intellect. Disabil. Res. 2016, 60, 756.

28. Xiao, G. Research and Reflection on the Application of Remote Live Teaching in Senior High School Chemistry Teaching-Take Shilin Yi Autonomous County No.1 Middle school as an example. Master's Thesis, Yunnan Normal University, Kunming, China, 2018.

29. Parasuraman, A.; Zeithaml, V.A.; Berry, L.L. SERVQUAL: A multiple-item scale for measuring consumer perceptions of service quality. J. Retail. 1988, 64, 12-40.

30. Chhay, L.; Mian, M.; Suy, R. Consumer responses to green marketing in Cambodia. Open J. Soc. Sci. 2015, 3, 86-94. [CrossRef]

31. Carlos Castro, J.; Quisimalin, M.; De Pablos, C.; Gancino, V.; Jerez, J. Tourism marketing: Measuring tourist satisfaction. J. Serv. Sci. Manag. 2017, 10, 280-308. [CrossRef]

32. Singh, S. Measuring E-service quality and customer satisfaction with Internet banking in India. Theor. Econ. Lett. 2019, 9, 308-326. [CrossRef]

33. Chang, W.; Ardiyanto, A.; Wu, C.; Lin, C. The application of SERVQUAL model to construct indicators for improvement of agricultural products exhibitions service quality. Open Access Libr. J. 2020, 7, 1-9. [CrossRef]

34. Cook, C.; Thompson, B. Reliability and validity of SERVQUAL scores used to evaluate perceptions of library service quality. J. Acad. Libr. 2000, 4, 248-258. [CrossRef]

35. Qian, J. Study and design on measurement of information service quality for academic library based on SERVQUAL. J. Acad. Libr. 2001, 4, 34-37.

36. Yu, L.-Z.; Gu, S.; Zhao, Z. SERVQUAL and quality assessment of library services: A review of research in the past decade. J. Acad. Libr. 2005, 22, 51-57.

37. Tan, J.; Pei, J. Study on the tools for evaluating the education quality of professional degree programs in China. Acad. Degrees Grad. Educ. 2008, 7, 45-50.

38. Zhu, Z.-L. The study on quality assessment model of distance learning support service. J. Distance Educ. 2009, 4, 19-22.

39. Martilla, J.; James, J. Importance-performance analysis. J. Mark. 1977, 41, 77-79. [CrossRef] 